Ząbkowicz A., Governing economic interests by the European Commission, „Ekonomia i Prawo. Economics and Law.”, Polszakiewicz B., Boehlke J. (ed.), Vol. 14, No. 1/2015, pp. 95-111. DOI: http://dx.doi.org/10.12775/EiP.2015.007.

\title{
GOVERNING ECONOMIC INTERESTS BY THE EUROPEAN COMMISSION
}

\author{
SUMMARY
}

The paper deals with contemporary phenomenon of "Europeanization" of lobbying activities. The aim is to survey the outcome of interdisciplinary research on interest representation in the EU context, with regard to the European Commission and business representation. The subject is a matter of interest to contemporary political economy seen as search for institutional equilibrium in relations between public authorities, the market and civil society. Political and information exchange is presented as an interplay between the demand side and the supply side. Deliberately, the paper is concerned with economic interests only, leaving citizen or social interests beyond the scope. The questions posed are about organizational forms of their coordination, basic standards of access, and transparency of the EC-business relations.

Keywords: interest representation, governance, European Union

JEL Classification: P16

\section{INTRODUCTION}

Contemporary political economy sees economic performance as an outcome of interaction between public authorities domain, market domain and

* Anna Ząbkowicz, Polish Academy of Sciences, Institute of Economic Sciences, Pałac Kultury i Nauki, Pl. Defilad 1, 00-901 Warszawa, phone: +48 2265727 07, e-mail: holic@ op.pl. 
civil society domain ${ }^{1}$. As long as combination of formal and informal institutions integrate these three domains, system tends toward institutional equilibrium and society is capable to function. Political-economical approach shares interest with political science in constitution, collective choice, group interests, institutions that matter (polity) and the concept of governance. Within this general perspective a survey of the outcome of interdisciplinary research will be tried referring to the European Union (EU) which constitutes a platform of communication between supranational public bodies and economic and social interest representations. The focus will be on the European Commission (EC) and business representation, with social and citizen interests skipped for reasons explained later. Can the central policy-making European institution be said to be skillful in governing economic interests?

Basically, interests, group interests, interest representation or lobbying groups here mean community of interests or views with its representatives addressing public bodies (legislature, government, supranational institution) with their own postulates or arguments in aim to change or conserve rules of the game $^{2}$. The literature differentiates between various categories such as business, professional, labour, public, social and territorial interests ${ }^{3}$. The talk recently is on "multi-level governance" that is a variety of interests on the supranational, national and regional levels.

The perspective of this paper focus on "European" level. Acceleration of integration process to be witnessed since the mid-1980s which resulted in the rise of European Union made it an even more attractive playground for lobbying. The more empowered European institutions were, the more determined specific interests got to incorporate them in their strategies. In scholarly dispute a notion of "Europeanization" has been introduced which can be most simply explained as thinking in supranational European terms ${ }^{4}$. Since the very beginning of the integration both national and functional interests have played role, which was reflected by a "classical" debate between neofunc-

1 See J.Wilkin, Koncepcja dobrze rządzonego państwa i uwarunkowania jej praktycznej realizacji, [in:] J. Wilkin (ed.), Teoria wyboru publicznego, Wydawnictwo Naukowe Scholar, Warszawa 2012, p. 275-277.

2 See R. Eising, Grupy interesów, [in:] M.Cini (ed.), Unia Europejska. Organizacja i funkcjonowanie, Polskie Wydawnictwo Ekonomiczne, Warszawa 2007, p. 275. Sometimes “interests" refer to individual firms active in political market as well.

${ }^{3}$ K. Charrad, Lobbying the European Union, Nachwuchsgruppe Europaeische Zivilgesellschaft, Westfallische Wilhelms-Universitaet Muenster 2007, p. 7.

${ }^{4}$ J.P. Olsen, Europeizacja, [in:] M.Cini (ed.), Unia Europejska. Organizacja i funkcjonowanie, Polskie Wydawnictwo Ekonomiczne, Warszawa 2007, p. 464-466. 
tionalism and so called intergovernmental approach ${ }^{5}$. In more recent years the debate turned rather to how the "additional" European tier operates and what is its impact on national patterns of interest intermediation and its effects on national policy ${ }^{6}$. The states still remain important players, however the focus re-shifted to non-public actors, and to their impact on European decision-making process ${ }^{7}$.

Accordingly, the paper says about trans-national interests active on the EU level. These used to be represented by federations of business and labour, with their significance stemming from their size, organizational capacity and long-standing structures which evolved originally under national corporatisms. Nowadays, labour seems to loose in significance in international rules setting, which goes with demise of national trade unions and severe pressures on the flexibility of domestic labour markets, and can be observed in the EU context as well. Consequently, the focal point are business interests which are widely seen as being dominant both numerically and politically in the EU arena. It is worth adding, that among interests approaching the UE institutions non-governmental organizations (NGOs) has gained significance in the last three decades. They are associated with "citizen", "social" or "diffuse" interests. However, these interest representations remain beyond the perspective of this paper which strives to trace institutional channels of access of major interests in the EU policy-making and law-making processes, and these stem mainly from business and finance.

Among European institutions the Commission is mostly prone to maintain close relations with business interests ${ }^{8}$. As far as Economic Community concerned, the European Commission holds monopoly of legislative initiatives as well as executive power which makes it rather attractive to group interests. What is not that obvious, EC is most eager to encourage them: "Among the European institutions, the European Commission has been most prominent to encourage trans-national interest group co-operation, to initiate European-wide networking and to provide benefits like privileged access

${ }^{5}$ Neofunctionalists, who believed group interests to constitute driving forces of European integration, being in the lead in the 1950s, withdrew and since the 1970s research focused mostly on interactions within or between the member states. Interest groups were reduced to the role of partners to their national governments with no great say in major policy decisions.

${ }^{6}$ P.A. Hall, Institutions and the Evolution of European Democracy, [in:] J. Hayward, A. Menon (ed.), Governing Europe, Oxford University Press, Oxford, New York 2003.

${ }^{7}$ K. Charrad, op. cit., p. 2.

${ }^{8}$ R.Eising, Grupy..., op. cit., p. 276-277; B. Kohler-Koch, Organized Interests in the EC and the European Parliament, European Integration online Papers, Vol. 1 No. 009/1997. 
or financial support" ${ }^{\prime 2}$ Why is it so? Due to democracy deficit dilemma the Commission is open to social consultation even more than the Parliament is. Secondly, to much extent it is structured accordingly to sector or functional logics like organized business normally is which makes inter-action with this category of interests easier ${ }^{10}$. Therefore, the EC-business relations seem to be of greatest interest to an economist.

The central question is how the European Commission governs business interests, which means tracing organizational forms of their coordination, basic standards of access and transparency of mutual relations. The perspective remains in the stream of contemporary research which has replaced the traditional studies on European polity. Naturally enough, at the first stage of European integration attention was mostly paid to formal institutions building. Institutions of state and Community, constitutional and codified rules were at stake. More recently, new institutionalism has added forms of social interaction that is procedures and behavioral standards (e.g. different cultures of Directorates Generale). This shifted the body of research from "government" to "governance", from treaties to practices ${ }^{11}$. Accordingly, this paper does not discuss constitutional competences and mutual relations of the European institutions (the Commission, the Parliament, the Council of Ministers, etc.) but it is concerned with rules governing cooperation (e.g. registration) as well as with institutional framework of intermediation (e.g. committees) between business interests and the Commission which are not necessarily official and obligatory.

The paper is structured in following order. To the EC-business relations the metaphor of political market is applied (section 1). Accordingly, business representation on the supply side (section 1.1), and access points and opportunities created by the Commission on the demand side (section 1.2) are demonstrated. Institutional perspective requires particular regard to rules of access which are discussed in section 2 . The analysis implies concerns about power advantage of business representations on the one hand, and about soft law governing interactions of business representatives with the Commission on the other hand.

\footnotetext{
${ }^{9}$ Ibidem, p. 2.
}

${ }^{10}$ M. Egeberg, Komisja Europejska, [in:] Cini M. (ed.), Unia Europejska. Organizacja i funkcjonowanie, Polskie Wydawnictwo Ekonomiczne, Warszawa 2007, p. 209.

${ }_{11}$ B. Rosamond, Nowe teorie integracji europejskiej, [in:] Cini M. (ed.), Unia Europejska. Organizacja i funkcjonowanie, Polskie Wydawnictwo Ekonomiczne, Warszawa 2007, p. 168-74. 


\section{THE METAPHOR OF POLITICAL MARKET}

The fundamental relationship between interests and European institutions is one of exchange ${ }^{12}$. The exchange of expert knowledge for influence takes place in peculiar political market. On the supply side private or social actors offer goods (expertise and specific information) in order to influence the decision making ${ }^{13}$. They are engaged in collective action of various organizational shape and of various degree of cooperation. National associations address mainly national governments and bureaucrats of the same nationality working in Brussels, but try to exert influence indirectly via European federations as well. Those, often referred to as Eurogroups are sector or cross-sector umbrella associations, containing national associations or firms, or both. Apart of membership in Eurogroups some large firms fund "in-house" lobbying in shape of offices staffed with their own individual representation. Those who cannot afford it, usually hire political consultants that is commercial lobbyists in fact $^{14}$. On the other side, the targeted EU institution, e.g. the Commission, demands specific information. Expertise from the private sector to understand the market (both the EU internal market and the domestic market) is required. There is also demand on information regarding aggregated sector needs and interests ${ }^{15}$.

Thus, the EU institutions constitute opportunity structure for lobbying groups in which to pursue their interests. Accordingly to the very meaning of institutions, they also "organize some conflicts into politics and some con-

12 K. Charrad, op. cit., p. 14.

${ }^{13}$ Economic theory of regulation points to corrupting the regulators in exchange for legal protection. Then an "offer" on the supply side can contain attractive goods with relatively low costs of their acquiring for decision-makers, preferential credit, high gratification - see S. Sztaba, Aktywne poszukiwanie renty. Teoria. Przyktady historyczne. Przejawy w polskiej gospodarce lat dziewięćdziesiątych, Monografie i Opracowania, No 501, SGH, Warszawa 2002, p. 14-15. The differentiation between lobbying and corruption depends on whether given activities comply with law, and is rather vague.

14 See R. Eising, Grupy..., op. cit., p. 282-283; I. Michalowitz, Two-way Strategy: Interest Intermediation or Mutual Instrumentalisation?, [in:] A.Warntjen, A.Wonka (eds), Governance in Europe. The Role of Interest Groups, Nomos Verlagsgesellschaft, Baden-Baden 2004, p. 77-78; P. Bouwen, A comparative study of business lobbying in the European Parliament, the European Commission and the Council of Ministers, MPIfG discussion paper, No. 02/7, Max Planck Institute for the Study of Societies, Kiel 2002, p. 24-26, http://hdl.handle. net/10419/43177 (30.09.2013).

${ }^{15}$ K. Charrad, op. cit., p. 9. 
flicts out of it" ${ }^{16}$. According to numerous scholars, however, their role is not confined to bargaining nor to intermediation lobbyists' interests. European institutions "pursue their own policy preferences in alliances with groups that are supportive of their case" 17 . An opinion is shared that "the private actors can only gain access [...] if they are simultaneously demanded by the targeted EU institution"18.

\subsection{ON THE SUPPLY SIDE: OVER-REPRESENTATION OF BUSINESS}

Among interest representations approaching the key EU institutional actors business interests are in the lead even though the significant increase in the number of citizen representations has reduced the extent of bias since the mid-1980s. According to the Commission registry of civil society organizations (CONECCS) of 2002, 80 per cent of the EU-level groups stemmed from business, and 20 per cent represented diffuse or public interests ${ }^{19}$. That is, 80 per cent of organizations, reported by the Commission, covered producers' or employers' interests ${ }^{20}$.

Business interests can be also measured as number of groups reporting activity in policy areas such as industry, agriculture and services. According to other Commission database of 2000 such interest was declared by 80 per cent of nearly 800 active groups ${ }^{21}$. Ch. Mahoney presents her own data according to the criterion of policy area, and adds an inspiring commentary. According to her findings, Enterprise generated the bulk of interest (more than 200 groups), however, the next highest levels of activity were Social Policy and Environmental Policy (circa 90 and 75 groups respectively), which are "policy areas that at first blush appear to be domain of citizen groups". The point is, that citizen groups are not the only participants in these areas, business being involved as well. Mahoney notes, "Business is greatly affected by EU environmental policy and employment policy and therefore actively protects its interests in debates concerning environmental legislation and worker health and safety" 22 . The Civil Society Database appears to sup-

${ }^{16}$ R. Eising, Interest groups in EU policy-making, Living Reviews in European Governance, CONNEX and NEWGOV, 2008, p. 9, www.ruhr-uni-bochum.de/sowi/pw2/ (30.09.2013).

17 Ibidem.

${ }^{18}$ K. Charrad, op. cit., p. 9.

19 R. Eising, Interest..., op. cit., p. 9.

${ }^{20}$ R. Eising, Grupy..., op. cit., p. 283.

${ }^{21}$ Ibidem, p. 281.

${ }^{22}$ Ch. Mahoney, The Power of Institutions: State and Interest Groups Activity in the European Union, „European Union Politics”, Vol. 5, No. 4/2004, p. 459. 
port this point: of the 93 groups that declared activities in the environmental policy area, business, professional and trade associations comprised $72 \%$ of participants, whereas citizen and cultural groups constituted only $19 \%{ }^{23}$. Obviously, not all interest groups are equally able to mobilize. Business capabilities in this respect make the problem of over-representation in relation to non-business interests even more profound.

The sound representation of business interests at the recent stage of integration can hardly be a surprise. At early stages of integration process, following the Rome Treaty encompassing cross-sector associations of industry and employers (UNICE, 1958) as well as industrial and commercial chambers (EUROCHAMBERS, 1958) were established. Economic interests mobilized and responded to major institutional change in the 1980s during implementing and enforcing the Single Internal Market and the Monetary Union projects, as well. In pushing integration towards the Single Market large business lobbying played a pivotal role. In the late 1970s and 1980s combination of "sticks and carrots" made large firms to act increasingly at the European level. The political decision to accelerate integration and to build new European institutions rose risks due to changing institutional opportunity structure (e.g. voting rules under the Single European Act, entailing the loss of member state vetoes in the Council of Ministers). This implied mobilization, especially of large private interests in order to build or extend more direct channels of access to decision-making and law-making process on the European level. On the other hand, the prospect of market integration promised new opportunities of doing business and prompted to engage into process of its institutionalization, in respect to the making both of a regional market and transnational economic regulation. The case of the European Round Table is often recalled. This advisory body of chairmen and top executives of big European companies had been created in 1983 to improve exchange between industrialists and governments, both at national and European levels. In 1984 it produced the "Agenda for Action- Europe 1990". It contained a good part of proposals captured from a memorandum to the European Parliament, submitted by a Dutch multinational Philips in 1980. The relationships can be traced as well between the ERT agenda and the then presented European Commission White Paper on the Internal Market ${ }^{24}$. Stories like this lend credibility to the neofunctionalist view that non-state lobbying is not non-sig-

${ }^{23}$ Ibidem, p. 460.

${ }^{24}$ W. Lehmann, Soft law or no law? The European Parliament's new role in the man-agement of organized interests, paper presented at the $10^{\text {th }}$ EUSA Meeting, Montreal 2007, p. 11, http:// aei.pitt.edu/7948/1/1ehmann\%2Dw\%2D08d.pdf (30.09.2013). 
nificant for European integration. Other case studies show that multinational firms were pushing governments into adoption of the Maastricht Treaty ${ }^{25}$. The growing importance of the EU has led to intensification of business lobbying in Brussels.

Large business lobbies the Commission on rather regular basis what other group interests can hardly afford. Business Eurogroups like CEFIC (chemical industry), COPA/COGECA (agriculture), CEA (insurance), etc. have relatively large resources at disposal. Normally, they maintain their bureaus in Brussels, whereas many other group interests hire consultants or representatives on ad-hoc and temporary basis. Some of Eurogroups are clearly governed by large producers, e.g. ACEA (automobiles) or APPE (petrochemicals) ${ }^{26}$. Moreover, the largest manufacturers of Europe (e.g. automakers) individually provide bureaus and regular staff for more direct lobbying,

In short, organized business, while seeking access to the European institutions for their regulatory powers, demonstrates the highest capability for self-organization and for exerting influence on the supply side of political exchange. The main target is the Commission due to its monopoly of legislative initiatives and its executive power in the economic policy pillar. What knowledge and expertise are demanded by the Commission, and which actors are preferred on the other side of political market?

\subsection{ON THE COMMISSION SIDE: PREFERENTIAL TREATMENT OF BUSINESS}

The importance of interest representation has been always emphasized by the Commission. The EC has been making considerable efforts towards comprehensive and early consultations. Culture of consultation and dialogue has been reinforced by European primary law. According to the Treaties, "the European Commission shall carry out broad consultations with parties concerned in order to ensure that the Union's actions are coherent and transparent"27. More precisely, "the Commission should [...] consult widely before proposing legislator and, whenever appropriate, publish consultation

${ }^{25}$ G. Schneider, D. Finke, K. Baltz, With a little help of the state: Interest intermediation in the domestic pre-negotiations of EU legislation, "Journal of European Public Policy", Vol. 14, No. 3/2007, p. 1.

${ }^{26}$ N. Nugent, Unia Europejska, Wydawnictwo Uniwersytetu Jagiellońskiego, Kraków 2012, p. 312-313.

${ }_{27}$ European Union, Consolidated version of the Treaty on European Union, Official Journal of the European Union, 30.3.2010, Art. 11.3, http://eur-lex.europa.eu/LexUriServ/LexUriServ. do?uri=OJ:C:2010:083:0013:0046:en:PDF, (30.09.2014). 
documents" ${ }^{28}$. Commission's prudence and open stance is continuously demonstrated in different issues of soft law, such as communiqués, White Papers, Green Papers etc.

Such law seems to be founded on a very real need of legitimization and support. Since this important European institution is no democratic body, the rules it provides need legitimization. The Commission, having opened access for various interests, seeks expertise and insider knowledge which may be useful in formulation of legislation. Moreover, special relations with influential sector interests matter due to effectiveness considerations. For instance, their support may be important for the Commisision's position in negotiations with the Council29.

In order to gain more expert knowledge and meritocratic support for its regular staff, the Commission has established a system of committees. They are institutional arrangements via which the Commission communicates what knowledge and expertise are demanded. Nearly 150 constant consultative committees which constitute only a portion of this system are to stimulate debate and activity on certain types of policy questions ${ }^{30}$. More than half of their activities is consumed by four policy areas: Agriculture, Employment and Social Affairs, Enterprise, and Environment. Two of them refer directly to "business" category, and the other two (Social Affairs, Environment) are penetrated by economic interests, according to the data reported before. Mahoney notes that it is likely to be a feedback process. Decisions in which areas the committees will be established are probably influenced by the activity of organized interests. However, the scholar concludes: "Although the supply-side force of interest group advocacy undoubtedly plays a role in the distribution of political attention, the Commission also wields substantial power. [...] the EU institutions have the ultimate say in whose voices are heard in the formal arenas of debate" 31 .

For the sake of legitimization, collective forms of representation are preferred, with Eurogroups being particularly encouraged or even favoured by the Commission. Namely, they are more likely to hold a seat in a Consultative Committee, and for some reasons the Commission is likely to listen to Eurogroups rather than to individual actors ${ }^{32}$. First, the EU "umbrella groups"

${ }^{28}$ W. Lehmann, op. cit., p. 12 , according yo the annex to Amsterdam Treaty.

${ }^{29}$ N. Nugent, op. cit., p. 315. Unification of international standards is often carried on provided support of multinationals or even due to their initiatives...

${ }^{30}$ Ch. Mahoney, op. cit., p. 448.

31 Ibidem, p. 449.

32 Ibidem, p. 453. 
are seen as being able to speak for a broader constituency than the groups organized at the national or sub-national levels. Second, it is technically more convenient for European bureaucrats to communicate with one over-arching supranational representation rather than with numerous national and sector associations ${ }^{33}$. According to the Bouwen's semi-structured interviews in 2003 European associations effectively enjoyed the highest degree of access, followed by national associations. Individual firms and consultants constituted hardly one third of the interests who won access to the Commission ${ }^{34}$. Among European associations some business federations enjoy a special treatment in terms of access and dialogue. Employers' and business umbrella representations (CEEP and BusinessEurope, former UNICE) enjoy a privileged status of social partners (along with labour representation ETUC). In practice, it means regular meetings and information exchange with the Commission with option of common legislative initiatives ${ }^{35}$.

However, encompassing organizations seem to loose weight at other points of access. Apart of the committees just discussed, the Commission's Directorates Generale (DGs) themselves constitute such points. Over time, DGs specializing in specific policy areas have established close links to sector interest groups or individual interests relevant for their agenda. Large business European groups enjoy permanent access as far as their policy area concerned $^{36}$, nevertheless, with narrow policy responsibilities of a DG narrow interests are welcomed as much as broad representation. Bouwen's other survey was founded on interviews with officials of the Internal Market DirectorateGeneral which can be identified as the leading Commission DG in the area of EU financial services. It pointed to individual firms as the second-best preference with very small loss to the leader, i.e. associations ${ }^{37}$. B. KohlerKoch comments, "Encompassing interest associations find it difficult to deliver in such a system. They neither command the necessary expert knowl-

${ }_{33}$ M. Egeberg, op. cit., p. 209.

${ }^{34}$ P. Bouwen, The Democratic Legitimacy of Business Interest Representation in the European Union: Normative Implications of the Logic of Access, Preprints of the Max Planck Institute for Research on Collective Goods, Bonn, No 8/2003. p. 13, graph 3.3.

35 N. Nugent, op. cit., p. 316; R.Eising, Grupy..., op. cit., p. 282.

36 The COPA may be an example. This agricultural producers' representation enjoys regular meetings with the commissary for agriculture; the general secretary of COPA contacts personally and by phone the head of the respective Directorate General, and the same refers to mutual contacts of the staff of both bureaus. Moreover, COPA is directly or indirectly represented in every consultative committee which deals with issues close to its policy area - N. Nugent, op. cit., p. 316.

37 P. Bouwen, $A$ comparative study..., op. cit., p. 25, table 7. 
edge nor the support of their members to become reliable partners in mutual agreements" ${ }^{\prime 8}$. Large firms are often consulted directly by the bureaucrats i.e. having skipped the layer of association. The trust-based relationships between Brussel bureaucrats and firms "in the inner circle" are compared to the regulatory-agency style ${ }^{39}$.

On its side te Commission is by no means passive and takes advantage of its empowerment for policy initiation. In the process of policy formation interest group representatives are called for expertise and interest input. To some extent, the Commission discriminates among them opening consultations and establishing committees in chosen policy areas. Those actors are able to influence initial policy proposals who gained access to the Commission, for instance were awarded membership in one of the Commission's formal Consultative Committees or became an appreciated partner of an individual DG. The survey above confirms that access to the Commission is very much biased towards business representation ${ }^{40}$. Some do not hesitate to state that "[b]usiness interests and particularly large firms are privileged governance partners of the EU institutions" ${ }^{1}$.

\section{RULES OF ACCESS: INSTITUTIONAL RESPONSES TO INCREASED LOBBYING}

As mentioned above, the Single Market project was welcomed by business (i.e. trade, industry and banking interests) for removal of barriers to trade, direct investment and capital transfers. However, projects such as the services directive, the roaming charges regulation or the single European payment area meet much less enthusiasm from private interests, being perceived as detrimental to profit-making. Following the 1986 Single European Act, the EU began attracting lobbyists in substantially large numbers. Given the intensification of lobbying since the late 1980s on the one hand, and the EU's democratic deficit on the other hand, a need for more transparency has become critical. Whereas an open character of the European Commission is out

${ }^{38}$ B. Kohler-Koch, op. cit., p. 4.

39 D. Coen, Empirical and theoretical studies in EU lobbying, "Journal of European Public Policy", Vol. 14, No. 3/2007 according to A. Hassel, Multi-level governance and organized interests, [in:] M. Zürn, H. Enderlein, S. Wälti (eds.), Handbook of Multi-Level Governance, Edward Elgar, Cheltenham, Northampton, MA 2010, p. 162.

40 Ibidem.

${ }^{41}$ R. Eising, Clientelism, Committees, Pluralism and Protests in the European Union: Matching Patterns?, „West European Politics”, Vol. 31, No. 6/2008, p. 1175. 
of question, it is much to be done about basic standards governing access. Increased lobbying is forcing the Commission to choose from a very broad range of approaching actors. There is controversy about selecting a number of privileged interlocutors, and about arbitrariness governing these choices ${ }^{42}$.

Regulations concerning lobbyists are soft, however. Rules of access, instead of binding legislation, appear in form of communications, guidelines, interpretative notes, etc. Interest groups are encouraged in self-regulation that is in putting together their own codes of conduct. As far as now, there is no official register of interests lobbying the Commission. Registering of lobbyists is voluntary. In effect, the exact number and diversity of interest groups in the Commission's environment is not known.

Soft law, that is "a variety of processes" which "have normative content [but] are not formally binding" ${ }^{43}$, has a long-standing tradition in European law and has always played an important role in European integration. The Treaty on European Community provides an article concerning nonbinding character of recommendations and opinions, though remains silent on the status of other soft law instruments that have frequently occurred in Community practice. It was primarily the Commission who developed soft law, and the European Court of Justice who strained to elaborate the nature and legal status of some soft law instruments ${ }^{44}$. Although other leading European institutions can create soft instruments as well, soft law issued by Commission used to function as an alternative to Community legislation

While the Parliament has laboriously established a compulsory system of lobbyists' registration, the Commission has acted in favor of their self-regulation ${ }^{45}$. According to the definition adopted by the European Commission in 2002, self-regulation means a large number of practices, common rules, codes of conduct and voluntary agreements which various groups (economic actors, social players, NGOs) establish themselves on a voluntary basis in order to regulate and organize their activities. Self-regulation is usually initiated by stakeholders and, unlike co-regulation, does not involve a legislative act ${ }^{46}$. In practice, as described by $\mathrm{D}$. Chabanet, professional associations claiming to speak on behalf of a particular constituency "do not have to submit to the rules of a representative body, the latter being considered a 'vital interlocu-

${ }_{2}$ Chabanet D., From Opacity to Transparency? The Place of organized Interests within the European Institutions, EUGOV Working Paper No. 27, Institut Universitari d'Estudis Europeus, Bellaterra 2011, p. 7-8.

${ }^{43}$ W. Lehmann, op. cit., p. 6.

${ }^{44}$ Ibidem, p. 5-6.

45 R. Eising, Grupy..., op. cit., p. 280.

${ }^{46}$ W. Lehmann, op. cit., p. 7. 
tor' and so obliged to work on binding rules and ultimately impose them on its members. Here private sector interest groups can put together all Codes of Conduct, Codes of Ethics and Codes of Practice they like, without getting too involved in formal consultation procedures that might be too restrictive, while still enjoying freedom of expression and a real right to hearing" ${ }^{47}$.

In the past some efforts have been made to put Commission's consultations into a bit more formal frames. These attempts repeatedly met calls from industry, trade and banking interests for soft-law instruments and self regulation. In Lehman's opinion, this is due to private interests a priori preference for the absence of regulation ${ }^{48}$.

In 2005 the European Transparency Initiative (ETI) was launched. This case, as presented by D. Chabanet and by C. McGrath ${ }^{49}$, seems to deliver the best insight to the issue of soft Commisssion's attitude and the idea of lobbyists' self-regulation. In 2004-2005 a couple of events constituted a highly unfavourable environment in respect of democratic status of the Commission and its self-legitimization. "No" to the proposed European Constitution in April 2005 made the EU's political future uncertain. In addition, the entry of ten new member states in 2004 fuelled widespread public fears. Public concerns have been gradually channeled i.a. in shape of the ALTER-EU movement (the Alliance for Lobbying Transparency and Ethics Regulation) since late 2004. Under such circumstances the Commission tried again to restart the integration process and, "much aware of its shaky democratic status", embarked on a program of self-legitimization. The ALTER-EU, consisting i.a. of the Eurogroups representing citizen interests which see themselves as mistreated by the current EU governance model, called for a binding system of compulsory regulation of business interests. It took advantage of officials' determination to counter the unfavourable atmosphere around EU integration and managed to gain access to high-ranking Commission staff. Its dense program of supervision, registration and transparency in the EU has influenced the Commission's thinking on lobbying regulation and constituted the background to the initiative, officially launched in March 2005 by Siim Kallas, the Vice-President of the European Commission and Commissioner for Administrative Affairs, Audit and Anti-Fraud. In reaction, lobbyists' associations defended the principle of self-regulation.

${ }^{47}$ D.Chabanet, op. cit., p. 11-12.

${ }^{48}$ W. Lehmann, op. cit., p. 20.

${ }^{49}$ D. Chabanet, op. cit., p. 9-10; C. McGrath, The development and regulation of lobbying in the new member states of the European Union, "Journal of Public Affairs”, Vol. 8, No. 1-2/2008, p. 22-23. 
The outcome, Green Paper on the European Transparency Initiative (ETI), published in May 2006 demonstrated ambivalence of the European Commission. On the one hand, it acknowledged lobbying as legitimate and useful part of a democratic structure, however, it voiced the Commission's "preference for the lobbying industry to operate the more rigorous form of self-regulation than is currently the case" 50 . Particularly, it said about "common (A.Z.) code of conduct, applicable to all lobbyists, monitored by a special umbrella organization" ${ }^{\prime}$. On the other hand, it postponed compulsory registration of interest groups postulated by the representatives of civil and social interests. It stated that "after a certain period" it would be re-considered whether the system of self-regulation had worked, and if not, whether a system of compulsory measures should be introduced ${ }^{52}$.

Two years later in May 2008 the Commission published a Communication that included a new Code of Conduct for Interest Representatives. It was followed by Register of Interest Representatives, established in June 2008. Previous Internet resource, based on voluntary self-descriptions of the organizations involved, was replaced with the list (also freely available online) under four headings: trade associations, "in-house" lobbyists, commercial lobbying consultancies and think-tanks. Subscribing to the register is still voluntary. However, to have a response made to a Commission under consultation considered, you need to register. In addition, it is conditioned to adherence to the code, which key rules are however "not particularly difficult for any organization which behaves ethically" ${ }^{3}$.

The Communication, being another manifestation of the Commission's soft stance was welcomed by neither of the parties involved. Consultancies and trade associations were concerned with client/member confidentiality and tax implications. On the other hand, ALTER-EU criticized the register as simply a token gesture. It seems that it remains much to be done as far as transparency of interests involved in the EU-making process concerned.

\section{CONCLUSION}

The EU is the closest realization of the idea of internal European market, brought up since the Treaty of Rome. Unsurprisingly, business has been

\footnotetext{
${ }^{50}$ C. McGrath, op. cit., p. 22.

51 Ibidem.

52 D.Chabanet, op. cit., p. 12-13.

${ }^{53}$ Ibidem, p. 13.
} 
in support of the Single Market project as well as the treaties on Economic and Monetary Union, with large transnational firms particularly involved. Since that time economic interests are eager more than ever to seek access to the European Commission who is the central actor in the economic policy pillar. Many arguments can be found for the EC to be open to consultation and expertise provided by organized interests. The involvement of the latter in policy- and law-making under integration process is widely accepted and their influence is perceived basically as beneficial to decision making.

Accepting the principle of representation and participation of different interests, scholars are concerned about evident power advantage of business representations on the one hand, and about soft law governing interactions of business representatives with the Commission on the other hand. Various indices reveal that business in the EU structures, and in the Commission environment especially, is over-represented in comparison with public or social interests. Its capability for mobilization seems to be considerably higher than that of "diffused" interests. Business lobbyists, like other representatives lobbying the Commission, enjoy the right for self regulation. There is no mandatory register nor precise categories which could be a help in stating who (e.g. association or single-firm "organization") and in whose sake is approaching the Commission. Among numerous interests representations the Commission officials choose arbitrarily because rules about preferences on the demand-side are soft. The picture gets even more blurred due to lobbying going on at different levels. Apart the European level which was referred to in this paper, expertise and influence can be transferred via national or even regional channels.

Such non-transparent environment can be favourable for those who have advantage in power and resources. The multi-level decision-making and soft rules seem to be best mastered by large business which is most capable to operate on different levels as well as has means to exert considerable pressure. This was the case of the Single Market project, described here as an instance. Scholars are inclined to see the evident activity of business interests in European arena as a result of these high capabilities as well as implication of maintaining interests in many policy areas ${ }^{54}$. Some studies (e.g. in environmental policies) confirm that business effectively dominates the policy area and has more influence on the legislative process then NGOs ${ }^{55}$. Business' advantages and asymmetry of power induce a question whether European policy-making is biased in the sense of favouring business interests to det-

\footnotetext{
54 R. Eising, Grupy..., op. cit., p. 286.

${ }_{55}$ Ch. Mahoney, op. cit., p. 459-460.
} 
riment of "adversary" interests, such as consumers and ecologists ${ }^{56}$. R. Eising reports that researchers are divided. Critical political economy suggests that "European integration promotes transnational neo-liberalism and spurs new transnational dynamics of European capital" ${ }^{57}$. Liberal studies share the view that large firms have become key players, however, the dialog between them and international institutions "need not always be unequivocally beneficial to international capital" 58 . Which of two stances is true remains open as a matter of professional's belief.

\section{BIBLIOGRAPHY}

Bouwen P., A comparative study of business lobbying in the European Parliament, the European Commission and the Council of Ministers, MPIfG discussion paper, No. 02/7, Max Planck Institute for the Study of Societies, Kiel 2002, http://hdl. handle.net/10419/43177 (30.09.2013).

Bouwen P., The Democratic Legitimacy of Business Interest Representation in the European Union: Normative Implications of the Logic of Access, Preprints of the Max Planck Institute for Research on Collective Goods, Bonn, No. 8/2003.

Chabanet D., From Opacity to Transparency? The Place of organized Interests within the European Institutions, EUGOV Working Paper No. 27, Institut Universitari d'Estudis Europeus, Bellaterra 2011.

Charrad K., Lobbying the European Union, Nachwuchsgruppe Europaeische Zivilgesellschaft, Westfallische Wilhelms-Universitaet Muenster 2007.

Coen D., Empirical and theoretical studies in EU lobbying, "Journal of European Public Policy", Vol. 14, No. 3/2007, http://dx.doi.org/10.1080/13501760701243731. Egeberg M., Komisja Europejska, [in:] Cini M. (ed.), Unia Europejska. Organizacja i funkcjonowanie, Polskie Wydawnictwo Ekonomiczne, Warszawa 2007.

Eising R., Clientelism, Committees, Pluralism and Protests in the European Union: Matching Patterns?, „West European Politics”, Vol. 31, No. 6/2008, http://dx.doi. org/10.1080/01402380802372647.

Eising R., Grupy interesów, [in:] M.Cini (ed.), Unia Europejska. Organizacja i funkcjonowanie, Polskie Wydawnictwo Ekonomiczne, Warszawa 2007.

Eising R., Interest groups in EU policy-making, Living Reviews in European Governance, CONNEX and NEWGOV, 2008, www.ruhr-uni-bochum.de/sowi/pw2/ (30.09.2013).

\footnotetext{
${ }^{56}$ N. Nugent, op. cit., p. 320.

${ }^{57}$ R. Eising, Interest..., op. cit., p. 18.

${ }^{58}$ Ibidem.
} 
European Union, Consolidated version of the Treaty on European Union, Official Journal of the European Union, 30.3.2010, http://eur-lex.europa.eu/LexUriServ/LexUriServ.do?uri=OJ:C:2010:083:0013:0046:en:PDF, (30.09.2014).

Hall P.A., Institutions and the Evolution of European Democracy, [in:] J. Hayward, A. Menon (ed.), Governing Europe, Oxford University Press, Oxford, New York 2003.

Hassel A.. Multi-level governance and organized interests, [in:] M. Zürn, H. Enderlein, S. Wälti (eds), Handbook of Multi-Level Governance, Edward Elgar, Cheltenham, Northampton, MA 2010.

Kohler-Koch B., Organized Interests in the EC and the European Parliament, European Integration online Papers, Vol. 1 No. 009/1997, http://eiop.or.at/eiop/texte/1997-009 a.htm.

Lehmann W., Soft law or no law? The European Parliament's new role in the management of organized interests, paper presented at the $10^{\text {th }}$ EUSA Meeting, Montreal 2007; http://aei.pitt.edu/7948/1/lehmann\%2Dw\%2D08d.pdf (30.09.2013).

Mahoney Ch., The Power of Institutions: State and Interest Groups Activity in the European Union, „European Union Politics”, Vol. 5, No. 4/2004, http://dx.doi. org/10.1177/1465116504047312.

McGrath C., The development and regulation of lobbying in the new member states of the European Union, „Journal of Public Affairs”, Vol. 8, No. 1-2/2008, http://dx.doi. org/10.1002/pa.284.

Michalowitz I., Two-way Strategy: Interest Intermediation or Mutual Instrumentalisation?, [in:] A.Warntjen, A.Wonka (eds), Governance in Europe. The Role of Interest Groups, Nomos Verlagsgesellschaft, Baden-Baden 2004.

Nugent N., Unia Europejska, Wydawnictwo Uniwersytetu Jagiellońskiego, Kraków 2012.

Olsen J.P., Europeizacja, [in:] M.Cini (ed.), Unia Europejska. Organizacja i funkcjonowanie, Polskie Wydawnictwo Ekonomiczne, Warszawa 2007.

Rosamond B., Nowe teorie integracji europejskiej, [in:] Cini M. (ed.), Unia Europejska. Organizacja i funkcjonowanie, Polskie Wydawnictwo Ekonomiczne, Warszawa 2007.

Schneider G., Finke D., Baltz K., With a little help of the state: Interest intermediation in the domestic pre-negotiations of EU legislation, "Journal of European Public Policy", Vol. 14, No. 3/2007, http://dx.doi.org/10.1080/13501760701243814.

Sztaba S., Aktywne poszukiwanie renty. Teoria. Przyktady historyczne. Przejawy w polskiej gospodarce lat dziewię́dziesiątych, Monografie i Opracowania, No. 501, SGH, Warszawa 2002.

Wilkin J., Koncepcja dobrze rzadzonego państwa i uwarunkowania jej praktycznej realizacji, [in:] J. Wilkin (ed.), Teoria wyboru publicznego, Wydawnictwo Naukowe Scholar, Warszawa 2012. 